\title{
Historias septentrionales cervantinas. Presentación
}

\section{Randi Lise Davenport}

UiT Universidad Ártica de Noruega

NORUEGA

randi.davenport@uit.no

[Hipogrifo (issn: 2328-1308), 7.1, 2019, pp. 9-11]

DOl: http://dx.doi.org/10.13035/H.2019.07.01.02

Los veintiún artículos reunidos en esta sección monográfica de la revista están dedicados al estudio de Los trabajos de Persiles y Sigismunda, historia setentrional de Miguel de Cervantes. Todos ellos tienen su origen en el congreso internacional «Cervantes en el Septentrión», que organizó la sección de español del Departamento de Lengua y Cultura de la UiT Universidad Ártica de Noruega, en Troms $\varnothing$, los días 27 al 29 de junio de 2017 con ocasión de celebrarse los 400 años de la publicación de la novela póstuma de Cervantes.

El objetivo de este encuentro fue reunir a los investigadores interesados en presentar y debatir el estado actual de la crítica sobre el Persiles. Y podemos concluir que con la participación de 80 cervantistas, de 18 países diferentes, se colmaron nuestras expectativas al respecto. Por ello agradecemos, a cada uno de los participantes, su contribución en dicho evento. También queremos extender nuestros agradecimientos al Grupo de Investigación Siglo de Oro (GRISO), de la Universidad de Navarra, y al Instituto de Estudios Auriseculares (IDEA) por su colaboración en la publicación de una selección de artículos en su prestigiosa revista Hipogrifo, y en la «Colección Batihoja» del IDEA, donde se publicarán otros 15 artículos, incluyendo las cuatro plenarias del congreso, que estuvieron a cargo de Frederick de Armas, Isabel Lozano-Renieblas, Michael Armstrong-Roche y José Manuel Lucía Megías. En ambos casos, nos complace de gran manera que los artículos sean de acceso abierto y estén disponibles para todo investigador interesado.

Antes de pasar a una breve introducción a los artículos aquí reunidos, tenemos que agradecer a las personas e instancias que hicieron posible la celebración de nuestro congreso: para empezar fue imprescindible el firme apoyo institucional y financiero en todos los niveles de la Universidad Ártica de Noruega, y también del Fondo de la Universidad, que ha hecho posible ambas publicaciones. Además, ha sido primordial el aval científico y apoyo entusiasta de dos presidentes de la Asociación de Cervantistas; primero José Manuel Lucía Megías, quien acogió con entusiasmo la idea de un congreso conmemorativo en el Septentrión, cuando le 
presentamos la idea en el año 2014; y luego, la presidenta del trienio 2015-18, Isabel Lozano-Renieblas que nos ha brindado invalorable ayuda y colaboración tanto antes como después del congreso.

Dada la convocatoria "septentrional" del congreso, no es de sorprender que el espacio asume un papel primordial en los trabajos, pero como señalaremos a continuación, se aborda desde enfoques y perspectivas muy variadas.

Siguiendo la senda de investigación "geocrítica", Hessel propone aprovechar el concepto de heterotopía de Foucault para demostrar la función de los espacios en la creación de los imaginarios colectivos en el Persiles, y así superar la dialéctica de la utopía / distopía. Johnson, a su vez, investiga desde la perspectiva de las llamadas "humanidades azules" o los "estudios oceánicos" el mar septentrional como espacio de emociones intensas. Sugiere que Cervantes, con sus propias experiencias extremas en las aguas del Mediterráneo, aprovecha los mares del norte como un "análogo exotizado" del Mare Nostrum, sugiriendo que mar y afecto constituye una figura complementaria potente para la exploración de las relaciones afectivas de los personajes. El trabajo de Poza analiza también el elemento del agua como conector de eventos e imágenes, proponiendo que Cervantes emplea una estrategia retórica que combina el arte de la memoria y la imaginatio compuesta. Llosa, al igual que Hessel, repara en que Periandro mismo se define como "lugar". Su perspectiva reúne de manera sugerente el arte de la memoria renacentista sobre el locus como espacialidad narrativa con las preocupaciones modernas de migración y marginación, demostrando cómo los "emigrantes forzosos" de la novela encuentran en el septentrión cervantino un lugar para sus narraciones de exilio. Otros trabajos examinan el espacio desde la funcionalidad de un lugar específico o simbólico, como la cueva en el artículo de Magrinyà, en el que este espacio fronterizo o liminar (según las teorías de Van Gennep y Turner) también se relaciona con cambios significativos en el nivel narrativo. Kamecke, por su parte, sostiene que la instancia narrativa del Persiles es de un carácter absoluto y soberano, lo que se revela entre otros casos en la correlación simétrica de los espacios y tiempos de la historia.

La traducción está íntimamente relacionada al espacio, tanto al novelesco como al extraliterario, lo que se tematiza de manera muy sugestiva en el trabajo de Nevoux, quien examina cómo las primeras traducciones del Persiles "trasladaron" la geografía nórdica, inclusive los espacios ficticios, a sus respectivos idiomas. Otro trabajo (Valera) ofrece una comparación entre la traducción "emblemática" decimonónica del Persiles al alemán, la de Dorothea Tieck, con la última traducción moderna de Petra Strien (2016). La cuestión idiomática dentro del espacio novelesco mismo es examinado en el trabajo de Sánchez, en relación con la búsqueda de la lengua perfecta para alcanzar la verdad absoluta en la época. Un "traslado de espacio" distinto - no entre idiomas, sino entre géneros - se problematiza en el trabajo de Escudero Baztán, quien examina cómo Rojas Zorrilla adapta la novela de Cervantes al espacio teatral áulico, lo que le obliga a tomar en cuenta no solo los cambios formales sino también las exigencias del público cortesano.

Otras contribuciones se enfocan en distintos personajes relacionados con el espacio septentrional: el artículo de Davenport pone a la "bárbara" Ricla bajo es- 
crutinio a través de una nueva lectura del conocido relato del naufragio de Pietro Querini, en la isla noruega de Røst, en el siglo XV, proponiéndolo como fuente de inspiración para el personaje. Colahan llama la atención sobre el nombre del rey septentrional, Cratilo, que Cervantes no habría encontrado en la Historia de las gentes septentrionales de Olao Magno, sino en La verdadera historia del rey Rodrigo del morisco Miguel de Luna, convirtiendo al rey visigodo corrupto que crea el historiador morisco, en rey godo y cristiano ejemplar en la historia septentrional cervantina. Un personaje septentrional que en ningún modo puede caracterizarse por su ejemplaridad es el desterrado inglés Clodio, cuya personalidad, más compleja, y que no puede reducirse a su "maledicencia", analiza Díaz de Alda, lanzando además la hipótesis de que el fraile dominico Juan Blanco de Paz es el trasfondo histórico del personaje murmurador y calumniador. Notamos entonces que varios artículos relacionan el espacio del cautiverio argelino con el espacio septentrional, aunque de modos distintos. Otro acercamiento a la cuestión de la elección de los nombres por parte del autor alcalaíno, es la de Escudero Buendía, quien se pregunta si hay una intención de "homenaje" hacia la familia de los Villaseñor del Quintanar de la Orden en el nombre del "bárbaro español" Antonio. Hipótesis que Escudero Buendía sostiene mediante la documentación de archivos. Un personaje de muy diferente tipo, con quien se encuentra Antonio en el Septentrión, es el licántropo, que Castells examina desde la perspectiva de la literatura fantástica, ofreciendo una comparación con una de las leyendas de Bécquer.

Espacios bien definidos o delimitados, en los que prevalecen la palabra y el debate en la obra, también son analizados según las varias posturas intelectuales sobre los temas que se ponen a prueba en ellos, como la cuestión del amor y los celos en la Academia de los Entronados en Milán (Arribas), o la antropología agustiniana y la corrupción de la voluntad en el palacio de Policarpo (McCallister). La temática religiosa, que se examina en el trabajo de Lamberti, no se limita al espacio urbano de Roma: la cuestión de cómo se presenta la ortodoxia se extiende a través del vasto espacio de la novela, estudiando Lamberti sus características peculiares y contradictorias.

Otros trabajos contribuyen a lo que podríamos llamar el "inventario del espacio novelesco del Persiles", demostrando la riqueza de la novela en este sentido, pero también señalando las sutiles funciones de por ejemplo la presencia de animales o representaciones animalescas (Rossiello), o del comer y del vestir (González) en la obra.

Y para terminar este muy breve repaso y dar paso a los trabajos propiamente dichos, hay que mencionar que tampoco falta el tema cervantista por excelencia, la metaficción, que Brito Díaz señala como una constante a través de todos los géneros de representación incluidos (comedia, flor de aforismos, lienzo, retrato...) en «esta novela preunamuniana de cómo se escribe y pinta la novela misma», demostrando que la lectura de esta historia setentrional como carente de interés metaliterario decididamente ha sido superado. 